\title{
Kdr-based insecticide resistance in Anopheles gambiae s.s populations in Cameroon: spread of the L1014F and L1014S mutations
}

Philippe Nwane ${ }^{1,2^{*}}$, Josiane Etang ${ }^{1,3}$, Mouhamadou Chouaïbou ${ }^{1,2}$, Jean Claude Toto ${ }^{1}$, Rémy Mimpfoundi ${ }^{2}$ and Frédéric Simard ${ }^{4}$

\begin{abstract}
Background: The spread of insecticide resistance in the malaria mosquito, Anopheles gambiae is a serious threat for current vector control strategies which rely on the use of insecticides. Two mutations at position 1014 of the $S_{6}$ transmembrane segment of domain II in the voltage gated sodium channel, known as kdr (knockdown resistance) mutations leading to a change of a Leucine to a Phenylalanine (L1014F) or to a Serine (L1014S) confer resistance to DDT and pyrethroid insecticides in the insect. This paper presents the current distribution of the kdr alleles in wild Anopheles gambiae populations in Cameroon.
\end{abstract}

Results: A total of 1,405 anopheline mosquitoes were collected from 21 localities throughout Cameroon and identified as An. gambiae $(N=1,248 ; 88.8 \%)$, An. arabiensis $(N=120 ; 8.5 \%)$ and An. melas $(N=37 ; 2.6 \%)$. Both $k d r$ alleles $1014 \mathrm{~F}$ and $1014 \mathrm{~S}$ were identified in the $\mathrm{M}$ and $\mathrm{S}$ molecular forms of An. gambiae s.s. The frequency of the $1014 \mathrm{~F}$ allele ranged from 1.7 to $18 \%$ in the $\mathrm{M}$-form, and from 2 to $90 \%$ in the S-form. The $1014 \mathrm{~S}$ allele ranged from $3-15 \%$ in the S-form and in the M-form its value was below 3\%. Some specimens were found to carry both resistant $k d r$ alleles.

Conclusion: This study provides an updated distribution map of the $k d r$ alleles in wild An. gambiae populations in Cameroon. The co-occurrence of both alleles in malaria mosquito vectors in diverse ecological zones of the country may be critical for the planning and implementation of malaria vector control interventions based on IRS and ITNs, as currently ongoing in Cameroon.

\section{Background}

Insecticide resistance is a major concern in all insect groups that are involved in crop destruction or in disease transmission. Four different types of mechanisms including behavioural avoidance, reduction of cuticle penetration, metabolic detoxification and reduced target-site sensitivity lead to insecticide resistance in many arthropod groups [1]. So far, metabolic detoxification and target site insensitivity have been demonstrated to play major roles in conferring resistance to insecticides in some arthropods [2]. While metabolic resistance is due to changes in the arthropod enzyme activity resulting in the detoxification or sequestration of the

\footnotetext{
* Correspondence: philino07@yahoo.fr

'Organisation de Coordination pour la lutte contre les Endémies en Afrique Centrale, Yaoundé, Cameroun

Full list of author information is available at the end of the article
}

insecticide, target site insensitivity is due to mutations preventing the binding of the insecticide to its target [3].

The target site of DDT and pyrethroid insecticides is the voltage-gated sodium channel. Different point mutations identified in the $\mathrm{S}_{6}$ transmembrane segment of domain II of this para-type sodium channel gene cause a change in affinity between insecticide and its binding site. This induces a phenotype termed knockdown resistance $(k d r)$ in a wide range of insects [4-6]. Different amino-acid substitutions occurring at variable positions on the voltagegated sodium channel have been reported in several studies. In most cases, the substitution of a Leucine residue to a Phenylalanine was commonly noted. At position 1014 the substitution of a Leucine residue to a Phenylalanine (L1014F) is observed in a range of arthropod species, including Musca domestica [7], Myzus persicae [8], Plutella xylostella [9], and the mosquito Anopheles gambiae 
[5], the major vector of human malaria in Africa. Another widespread mutation changes the Leucine at position 1014 to a Serine (L1014S) in wild populations of $A n$. gambiae [6]. In An. gambiae, the L1014F mutation is widely distributed in West and Central Africa, whereas the L1014S mutation has a much more restricted geographic range in Eastern Africa [10]. The spread of these mutations in wild populations of $A n$. gambiae threatens the effectiveness of malaria vector control strategies based on the use of chemical insecticides, and prompts for surveillance and monitoring [11].

Today, pyrethroid insecticides are most recommended for use in public health because of their high effectiveness and strong excito-repellent effect on insects, as well as low mammalian toxicity $[12,13]$. These insecticides make up around $40 \%$ of chemical insecticides used globally each year for indoor residual spraying of houses against malaria mosquitoes, and $100 \%$ of the WHOrecommended insecticides for the treatment of mosquito nets are pyrethroids [14]. Vector control is a key strategy in reducing malaria transmission and prevalence in endemic countries $[15,16]$. This strategy is chiefly based on the use of chemical insecticides for indoor residual spraying (IRS) and impregnation of bed nets for killing adult mosquitoes [17-19]. Pyrethroid-impregnated nets are therefore being massively scaled-up in Africa, but there is serious concern about the likely evolution of widespread pyrethroid resistance among Anopheles gambiae mosquito populations.

In Cameroon, insecticide treated nets (ITNs) are used for malaria vector control since the year 2000, although implementation varies depending on local capacity [20]. The level and spread of resistance to DDT and pyrethroids (deltamethrin, permethrin, lamda-cyalothrin) has been reported in several malaria vector populations mainly in An. gambiae s.s and An. arabiensis [21-23]. Moreover, it was demonstrated that enzyme systems such as esterases, gluthatione S-transferases and cytochrome $\mathrm{P}_{450}$ monooxygenases are implicated in the resistance of these mosquito populations [24-26], and both $k d r$ mutations were reported [27]. However, little is known about the geographic distribution and frequency of both $k d r$ mutations throughout the country.

The current report provides a detailed update of the occurrence, frequency and geographic distribution of both L1014F and L1014S $k d r$ mutations within and among An. gambiae populations from throughout Cameroon.

\section{Methods}

\section{Study sites}

Mosquitoes were sampled in 21 locations (Table 1) spanning the whole of Cameroon, and spread across its four main geographic areas: i) the forest area located in the southern part of the country which extends from latitude $2^{\circ}$ to $6^{\circ}$ North and experiences typical Equatorial Guinean climate with average yearly rainfall between 1,500-2,000 mm spread out over 4 seasons: 2 dry seasons (DecemberFebruary and July-August) and 2 rainy seasons (March-June and September-November). Mean annual temperature is $25^{\circ} \mathrm{C}$ [28]. Five localities were sampled in this area (Table 1).

ii) the coastal area situated alongside the Atlantic ocean, exposed to equatorial climate characterized by a long rainy season (March-November) with high annual rainfall between 2,000-10,000 $\mathrm{mm}$ and average annual temperature at $26^{\circ} \mathrm{C}$ [29]. A total of ten localities were visited in this area (Table 1 ).

iii) the western highlands located in the South-Western region of Cameroon. The area is characterized by one dry season between November and February and one rainy season between March and October with a mean annual rainfall of $1,800-2,500 \mathrm{~mm}$ and average yearly temperature below $22^{\circ} \mathrm{C}$ [28]. In this part of the country, mosquito collections were carried out in three localities (Table 1).

iv) the northern savannas exposed to tropical climate, subdivided into the humid tropical and Sahelian climate domains [28,29]. The humid tropical domain extends from about latitude $6^{\circ}$ to $10^{\circ}$ North and is characterized by 2 seasons: one dry season from November to May and one rainy season from June to October with an average yearly rainfall between 700 and $1,000 \mathrm{~mm}$, and mean annual temperature around $26^{\circ} \mathrm{C}$. The Sahelian climate domain encompasses the northernmost areas of the country, North of the Benue basin. The region receives annual rainfalls below $900 \mathrm{~mm}$, and experiences a long dry season of more than 7 months (OctoberMay) with annual temperature around $28^{\circ} \mathrm{C}$ [28]. Mosquitoes were collected in three localities (Table 1).

\section{Mosquito collections and species identification}

Mosquitoes were collected between May 2005 and May 2007 according 3 sampling methods [30]:

i) the dipping method (LC in Table 1), used to collect anophelines larvae and pupae from breeding sites using tanks, ladles, sieves and pipettes. In each study site, collections were performed in 10-15 breeding sites with 10-20 larvae collected per breeding site and reared locally until adult emergence;

ii) the indoor resting collection method, used to collect adult mosquitoes with mouth operated aspirators in human dwellings (CA in Table 1);

iii) the light trap method, used for the collection of anthropophagic adult mosquitoes with miniature light traps operated in dwellings during the night (LT in Table 1). 
Table 1 Molecular identification of members of the Anopheles gambiae complex collected in Cameroon

\begin{tabular}{|c|c|c|c|c|c|c|c|c|c|}
\hline \multirow{2}{*}{$\begin{array}{l}\text { Geogra- } \\
\text { phic area }\end{array}$} & \multirow[t]{2}{*}{ Locality } & \multirow{2}{*}{$\begin{array}{l}\text { Geographic } \\
\text { coordinates }\end{array}$} & \multirow{2}{*}{$\begin{array}{l}\text { Sampling } \\
\text { period }\end{array}$} & \multirow{2}{*}{$\begin{array}{l}\text { Sampling } \\
\text { method }\end{array}$} & \multirow{2}{*}{$\begin{array}{l}\text { Climatic and ecological } \\
\text { domains }\end{array}$} & \multirow[t]{2}{*}{ An. arabiensis } & \multicolumn{2}{|c|}{ An. gambiae s.s } & \multirow{2}{*}{$\begin{array}{l}\text { An. } \\
\text { mela }\end{array}$} \\
\hline & & & & & & & M-form & S-form & \\
\hline \multirow[t]{5}{*}{ Forest } & Ngousso & $\begin{array}{l}03^{\circ} 53^{\prime} 44^{\prime \prime} \mathrm{N}-11^{\circ} \\
3318^{\prime \prime} \mathrm{E}\end{array}$ & May 2006 & LC & Equatorial forest, urban & - & 57 & 6 & - \\
\hline & Nkolondom & $\begin{array}{l}03^{\circ} 56^{\prime} 52^{\prime \prime} \mathrm{N}-11^{\circ} \\
3018^{\prime \prime} \mathrm{E}\end{array}$ & Dec 2005 & LC & $\begin{array}{l}\text { Equatorial forest, market } \\
\text { gardening area }\end{array}$ & - & - & 64 & - \\
\hline & Dabadi & $\begin{array}{l}05^{\circ} 36^{\prime} 10^{\prime \prime} \mathrm{N}-13^{\circ} \\
37^{\prime} 50^{\prime \prime} \mathrm{E}\end{array}$ & May 2006 & LC & Equatorial/Tropical, urban & - & - & 72 & - \\
\hline & Italie & $\begin{array}{l}05^{\circ} 36^{\prime} 07^{\prime \prime} \mathrm{N}-13^{\circ} \\
44^{\prime} 22^{\prime \prime} \mathrm{E}\end{array}$ & May2006 & LC & Equatorial/Tropical, urban & - & - & 75 & - \\
\hline & Nkolbikon & $\begin{array}{l}05^{\circ} 36^{\prime} 06^{\prime \prime} \mathrm{N}-13^{\circ} \\
40^{\prime} 30^{\prime \prime} \mathrm{E}\end{array}$ & May 2006 & LC & Equatorial/Tropical, urban & - & 22 & 55 & - \\
\hline \multirow[t]{10}{*}{ Coastal } & Ipono & $\begin{array}{l}02^{\circ} 22^{\prime} 29^{\prime \prime} \mathrm{N}-09^{\circ} \\
52^{\prime} 28^{\prime \prime} \mathrm{E}\end{array}$ & Dec. 2005 & $\mathrm{LT}+\mathrm{CA}$ & Equatorial, humid forest, rural & - & 22 & 14 & 37 \\
\hline & Campo & $\begin{array}{l}02^{\circ} 22^{\prime} 30^{\prime \prime} \mathrm{N}-09^{\circ} \\
49^{\prime} 33^{\prime \prime} \mathrm{E}\end{array}$ & Dec. 2005 & $\mathrm{LC}+\mathrm{CA}$ & $\begin{array}{l}\text { Coastal equatorial, humid } \\
\text { forest, rural }\end{array}$ & - & 37 & 39 & - \\
\hline & Kribi & $\begin{array}{l}02^{\circ} 56^{\prime} 33^{\prime \prime} \mathrm{N}-09^{\circ} \\
54^{\prime} 26^{\prime \prime} \mathrm{E}\end{array}$ & Dec. 2005 & LC & $\begin{array}{l}\text { Coastal equatorial, humid } \\
\text { forest, urban }\end{array}$ & - & 62 & 11 & - \\
\hline & Bonamikengué & $\begin{array}{l}03^{\circ} 48^{\prime} 18^{\prime \prime} \mathrm{N}-10^{\circ} \\
08^{\prime} 08^{\prime \prime} \mathrm{E}\end{array}$ & Oct. 2005 & LC & Coastal forest, urban & - & 64 & 4 & - \\
\hline & Bonanloka & $\begin{array}{l}04^{\circ} 01^{\prime} 43^{\prime \prime} \mathrm{N}-09^{\circ} \\
43^{\prime} 54^{\prime \prime} \mathrm{E}\end{array}$ & May 2005 & LC & Coastal, equatorial, urban & - & 38 & 24 & - \\
\hline & Bonanjo & $\begin{array}{l}04^{\circ} 02^{\prime} 22^{\prime \prime} \mathrm{N}-09^{\circ} \\
41^{\prime} 13^{\prime \prime} \mathrm{E}\end{array}$ & Oct. 2005 & LC & Coastal equatorial, urban & - & 61 & 2 & - \\
\hline & Bonassama & $\begin{array}{l}04^{\circ} 04^{\prime} 26^{\prime \prime} \mathrm{N}-09^{\circ} \\
41^{\prime} 06^{\prime \prime} \mathrm{E}\end{array}$ & Oct. 2005 & LC & Coastal equatorial, urban & - & 74 & - & - \\
\hline & Loum & $\begin{array}{l}04^{\circ} 42^{\prime} 13^{\prime \prime} \mathrm{N}-09^{\circ} \\
44^{\prime} 03^{\prime \prime} \mathrm{E}\end{array}$ & Oct. 2005 & LC & Equatorial forest, suburban & - & 77 & - & - \\
\hline & Tiko & $\begin{array}{l}04^{\circ} 05^{\prime} 22^{\prime \prime} \mathrm{N}-09^{\circ} \\
21^{\prime} 09^{\prime \prime} \mathrm{E}\end{array}$ & Nov. 2005 & LC & Equatorial forest, urban, & - & 47 & 18 & - \\
\hline & Idenau & $\begin{array}{l}04^{\circ} 13^{\prime} 23^{\prime \prime} \mathrm{N}-08^{\circ} \\
58^{\prime} 13^{\prime \prime} \mathrm{E}\end{array}$ & Nov. 2005 & LC & Coastal equatorial, suburban & - & 18 & - & - \\
\hline \multirow[t]{3}{*}{ Highland } & Mangoum & $\begin{array}{l}05^{\circ} 28^{\prime} 35^{\prime \prime} \mathrm{N}-10^{\circ} \\
35^{\prime} 18^{\prime \prime} \mathrm{E}\end{array}$ & Oct. 2005 & LC & $\begin{array}{l}\text { Tropical, grassland mountains, } \\
\text { market gardening area }\end{array}$ & - & - & 76 & - \\
\hline & Makoutchietoum & $\begin{array}{l}05^{\circ} 36^{\prime} 37^{\prime \prime} \mathrm{N}-10^{\circ} \\
36^{\prime} 24^{\prime \prime} \mathrm{E}\end{array}$ & Oct. 2005 & LC & $\begin{array}{l}\text { Tropical, grassland mountains, } \\
\text { market gardening area }\end{array}$ & - & - & 77 & - \\
\hline & Magba & $\begin{array}{l}05^{\circ} 58^{\prime} 10^{\prime \prime} \mathrm{N}-11^{\circ} \\
13^{\prime} 38^{\prime \prime} \mathrm{E}\end{array}$ & Oct. 2005 & LC & $\begin{array}{l}\text { Tropical, transition forest/ } \\
\text { savanna, rural }\end{array}$ & 1 & - & 62 & - \\
\hline \multirow[t]{3}{*}{$\begin{array}{l}\text { Northern } \\
\text { savanna }\end{array}$} & Tibati & $\begin{array}{l}06^{\circ} 28^{\prime} 12^{\prime \prime} \mathrm{N}-12^{\circ} \\
37^{\prime} 20^{\prime \prime} \mathrm{E}\end{array}$ & May 2007 & $\mathrm{LC}+\mathrm{LT}$ & $\begin{array}{l}\text { Tropical, humid savanna, } \\
\text { suburban }\end{array}$ & 14 & - & 50 & - \\
\hline & Ngaoundéré & $\begin{array}{l}07^{\circ} 19^{\prime} 04^{\prime \prime} \mathrm{N}-13^{\circ} \\
35^{\prime} 38^{\prime \prime} \mathrm{E}\end{array}$ & Oct. 2006 & LC & Tropical, humid savanna, urban & 45 & - & 16 & - \\
\hline & Pitoa & $\begin{array}{l}09^{\circ} 23^{\prime} 31^{\prime \prime} \mathrm{N}-13^{\circ} \\
30^{\prime} 09^{\prime \prime} \mathrm{E}\end{array}$ & Oct. 2006 & LC & $\begin{array}{l}\text { Tropical, dry savanna, } \\
\text { suburban, cotton area }\end{array}$ & 60 & - & 4 & - \\
\hline
\end{tabular}

LC: larval collection, LT: Light trap; CA: capture with aspirators

Adult mosquitoes were morphologically identified in the field using reference keys [31,32]. They were stored individually in labelled tubes with a desiccant and kept in storage boxes at $-20^{\circ} \mathrm{C}$ in the laboratory for further analyses.

\section{Molecular identification and $k d r$ genotyping}

DNA was extracted from each mosquito specimen using the method of Collins and colleagues [33] and individual mosquitoes were identified down to their species and molecular form using PCR-RFLP [34]. This method allows simultaneous identification of the $\mathrm{M}$ and $\mathrm{S}$ molecular forms within An. gambiae s.s, as well as the other species of the An. gambiae complex. $K d r$ alleles were genotyped using hot oligonucleotide ligation assay (HOLA) as described by Lynd and colleagues [35].

\section{Statistical analysis}

Proportions of molecular forms and $k d r$ allele frequencies with their respective confidence intervals were 
determined using bootstrap statistical inference. The method is based on building a sampling distribution by re-sampling from field collected data. Data processing was performed using Excel and R softwares (R Development Core Team, 2005). The distribution of genotypes at the $k d r$ locus was tested for conformity to HardyWeinberg equilibrium within each molecular form and collection site, using exact tests available in GENEPOP 3.3 software [36].

\section{Results}

A total of 1,405 anopheline mosquitoes from the $A n$. gambiae complex were collected in 21 sampling sites with at least 60 specimens per site, except in Idenau (coastal area) where only 18 individuals were collected (Table 1).

\section{Species and molecular form distribution}

Three anopheline species were identified among the specimens collected in the 21 prospected sites: $A n$. melas, An. arabiensis and An. gambiae s.s.. Anopheles melas was collected at the adult stage in Ipono where it represented $50 \%$ of the total number of mosquitoes collected in this locality situated in the mangrove area of coastal Cameroon. Anopheles arabiensis was collected in the western highlands and in the northern savannas areas, at increasing frequencies when moving northwards (Table 1). Anopheles gambiae s.s was sampled in all sites: it was the only species of the complex surveyed in the southernmost sites, and decreased in frequency when moving northwards (Table 1). Both $\mathrm{M}$ - and Sform mosquitoes were found among the samples and occurred together in 9/21 localities (Table 1). The Mform was widespread and predominant in the coastal area characterized by abundant rainfalls and maximum relative humidity, as well as in large urban centres in the forest area. No An. gambiae M-form was found in the highlands area, as well as in the northern savannas. The $\mathrm{S}$ molecular form was found in $18 / 21$ sites, being predominant in the rural areas and suburban zones (Table 1). In the highlands and northern savannas areas, An. gambiae s.s. samples were essentially made up with the $\mathrm{S}$ molecular form. Proportions of this molecular form were $<40 \%$ in the coastal area, except in Campo where the proportions of the 2 forms were nearly equal. No M/S hybrid was found in our samples even in sites where $\mathrm{M}$ and $\mathrm{S}$ were sympatric.

\section{Distribution of the $k d r$ alleles}

All three $k d r$ alleles (1014L, 1014F and 1014S) were detected in both molecular forms of An. gambiae s.s. (Table 2), although at markedly different frequencies and with strong geographical variation within form. In the $\mathrm{M}$ molecular form, the $1014 \mathrm{~F}$ allele was detected in
$7 / 12$ samples, at a frequency always below 20\% (Table 2 Figure 1A). The highest frequencies were observed in the coastal area, especially in Bonanjo and Bonassama which are two central districts of Douala, the biggest harbour of Cameroon. In Nkolbikon, in the easternmost part of the forest area of South Cameroon where the $1014 \mathrm{~F}$ allele occurs at c.a. $7 \%$ in the M-form population, the $1014 \mathrm{~S}$ allele was observed in one M-form specimen, at the heterozygous state.

Elsewhere (e.g in 5/12 localities), all M-form specimens carried the susceptible 1014L allele at the homozygous state. Hardy-Weinberg proportions were generally respected, except in two cases in M-form populations from the coastal area (Table 2). These significant departures were associated with a deficit in heterozygotes. In the S molecular form, the 1014F allele was observed in all sites, except in 2 locations where sample sizes were very low $(\mathrm{N}=4$, Table 2$)$. The frequency of this allele ranged from $\approx 3 \%$ in Tiko (coastal area) to $88 \%$ in Makoutchietoum (highland area). Globally, the highest frequencies of this allele were recorded in the highlands and forest areas, and were lowest in the northern savannas (Table 2 Figure 1B). The 1014 S allele was detected in 12 out of $18 \mathrm{~S}$-form samples, at a frequency ranging from 3 to $15 \%$. The allele was spread throughout all ecological zones of Cameroon, reaching its highest frequencies in $\mathrm{S}$-form populations from the forest and highlands areas. Significant $(p<0.05$, single test level) departures from Hardy-Weinberg proportions were observed in 3 out of 10 populations tested (Nkolondom, Campo and Tibati, Table 2). These departures were associated with deficits in heterozygotes. All $A n$. arabiensis $(\mathrm{N}=120)$ and An. melas $(\mathrm{N}=37)$ specimens tested were homozygous for the susceptible $1014 \mathrm{~L}$ allele at the $k d r$ locus.

\section{Discussion}

The distribution of species within the An. gambiae complex observed in this study is in agreement with the known biology of these taxa $[32,37]$. As for the M and S molecular forms of An. gambiae s.s, their distribution and ecological requirements agree with previous studies carried out in Cameroon [38-40]. The presence of $A n$. arabiensis was almost exclusive in the northern savanna area characterized by a drier climate and mean annual rainfall below $1,000 \mathrm{~mm}$, in agreement with the ecological features described in previous studies. Anopheles melas was identified in Ipono, a rural locality situated in the mouth of the Ntem river in the coastal area. The locality is surrounded by mangrove swamps, which are typical breeding sites for this species. Anopheles melas represented c.a. $50 \%$ of the total mosquitoes collected at the adult stage in this locality, confirming its anthropophilic and endophilic behavior $[38,41,42]$. 
Table 2 Frequency of $k d r$ alleles in Anopheles gambiae s

\begin{tabular}{|c|c|c|c|c|c|c|c|c|}
\hline \multirow[t]{2}{*}{ An. gambiae s.s } & \multirow[t]{2}{*}{ Geographic area } & \multirow[t]{2}{*}{ Locality } & \multirow{2}{*}{$\mathrm{N}$} & \multicolumn{3}{|c|}{ Allelic frequencies (\%) } & \multirow[t]{2}{*}{$F_{1 S}$} & \multirow[t]{2}{*}{$\mathrm{p}(\mathrm{HW})$} \\
\hline & & & & $\mathrm{f}(1014 \mathrm{~L})[95 \% \mathrm{Cl}]$ & $\mathrm{f}(1014 \mathrm{~F})[95 \% \mathrm{Cl}]$ & $\mathrm{f}(1014 \mathrm{~S})[95 \% \mathrm{Cl}]$ & & \\
\hline \multirow[t]{12}{*}{ M-form } & Forest area & Ngousso & 57 & 98.2 [95.5-100] & $1.7[0-4.5]$ & 0 & -0.009 & 0.991 \\
\hline & & Nkolbikon & 22 & 90.9 [79.2-100] & $6.8[0-18.2]$ & $2.3[0-7.5]$ & - & - \\
\hline & Coastal area & Ipono & 22 & 100 & 0 & 0 & - & - \\
\hline & & Campo & 37 & 100 & 0 & 0 & - & - \\
\hline & & Kribi & 62 & $95.2[91.2-98.4]$ & $4.8[1.5-8.8]$ & 0 & -0.043 & 0.877 \\
\hline & & Bonamikengué & 64 & 100 & 0 & 0 & - & - \\
\hline & & Bonanloka & 38 & 100 & 0 & 0 & - & - \\
\hline & & Bonanjo & 61 & 81.9 [73.8-89.5] & 18.0 [10.5-26.2] & 0 & +0.342 & 0.027 \\
\hline & & Bonassama & 74 & $87.2[80.4-93.2]$ & 12.8 [6.8-19.6] & 0 & +0.462 & 0.011 \\
\hline & & Loum & 77 & 100 & 0 & 0 & - & - \\
\hline & & Tiko & 47 & 94.7 [90-98.9] & 5.3 [1.1-10] & 0 & -0.045 & 0.911 \\
\hline & & Idénau & 18 & 91.7 [83.3-100] & $8.3[0-16.7]$ & 0 & - & - \\
\hline \multirow[t]{18}{*}{ S-form } & Forest area & Ngousso & 6 & $16.7[0-50]$ & 75.0 [35.7-100] & 8.3 [0-25] & - & - \\
\hline & & Nkolondom & 64 & $35.9[25.8-46.1]$ & 60.2 [50-70.3] & 3.9 [0.8-8.6] & +0.452 & 0.005 \\
\hline & & Dabadi & 72 & 39.6 [31.9-47.9] & 46.5 [38.2-54.2] & $13.9[8.3-19.4]$ & -0.001 & 0.583 \\
\hline & & Italie & 75 & 25.3 [19.3-32.0] & $62.7[55.33-70]$ & $12.0[7.3-17.3]$ & -0.103 & 0.172 \\
\hline & & Nkolbikon & 55 & 32.7 [24.1-41.2] & $60.9[51.7-70.2]$ & $6.4[2.5-11.2]$ & +0.019 & 0.538 \\
\hline & Coastal area & Ipono & 14 & $71.4[54.2-87.5]$ & $25.0[11.5-38.2]$ & $3.6[0-11.5]$ & - & - \\
\hline & & Campo & 39 & $60.2[47.1-73.3]$ & 29.5 [17.9-41.9] & $10.3[3.6-18.2]$ & +0.346 & 0.005 \\
\hline & & Kribi & 11 & 36.4 [13.6-60] & 54.5 [33.3-75] & 9.1 [0-22.2] & - & - \\
\hline & & Bonamikengué & 4 & 100 & 0 & 0 & - & - \\
\hline & & Bonanloka & 24 & 89.6 [78.6-98.1] & $10.4[1.9-21.4]$ & 0 & - & - \\
\hline & & Bonanjo & 2 & $25.0[0-50]$ & 75.0 [0-100] & 0 & - & - \\
\hline & & Tiko & 18 & 97.2 [90.6-100] & $2.8[0-9.4]$ & 0 & - & - \\
\hline & Highland area & Mangoum & 76 & $0.6[0-1.9]$ & 84.9 [79.6-90.1] & $14.5[9.2-19.7]$ & +0.001 & 0.577 \\
\hline & & Makoutchietoum & 77 & $0.6[0-1.9]$ & 88.3 [83.8-92.9] & $11.0[6.5-15.6]$ & -0.1350 & 0.250 \\
\hline & & Magba & 62 & 57.3 [47.6-66.9] & 37.9 [29.8-46.8] & 4.8 [1.6-8.9] & +0.088 & 0.161 \\
\hline & Northern savannah area & Tibati & 50 & $91.0[83-97]$ & $9.0[3-17]$ & 0 & +0.631 & 0.005 \\
\hline & & Ngaoundéré & 16 & $78.1[56.2-93.7]$ & $18.7[3.1-37.5]$ & $3.1[0-9.4]$ & - & - \\
\hline & & Pitoa & 4 & 100 & 0 & 0 & - & - \\
\hline
\end{tabular}

$\mathrm{f}()$ : frequency of the allele (in \%); [95\%Cl]: $95 \%$ confidence interval; N: number of mosquitoes; $\mathrm{p}(\mathrm{HW})$ : probability of the exact test for goodness of fit to HardyWeinberg equilibrium; in bold: Significant value $(\mathrm{p}(\mathrm{HW})<0.05$, single test level); Fis is calculated according to Weir and Cockerham, 1984. Positive Fis indicates a deficit of heterozygotes and negative Fis indicates an excess of heterozygotes; -: not determined because no polymorphism observed and/or $\mathrm{N}<30$.

An. gambiae s.s. was the most frequent species of the complex collected during this study. This species exhibits two distinctive molecular forms termed $\mathrm{M}$ and $\mathrm{S}$ characterized by fixed nucleotide difference in the intergenic spacer of the ribosomal DNA [43,44]. Genetic differentiation between these molecular forms is high only in two or three tiny genomic areas named the speciation islands (representating 1\% of the total genome), with low or no differentiation found across most of the genome [45-47]. It is likely that the $\mathrm{M}$ and $\mathrm{S}$ molecular forms are distinct species [48,49], and there are distinct differences in the assortment of insecticide resistance genotypes and phenotypes between them. In this study, the two molecular forms of this species were identified in the samples, occurring at various relative frequencies from one site to another. The absence of MS hybrids reinforces previous findings for strong genetic isolation of the $\mathrm{M}$ and $\mathrm{S}$ forms in Cameroon [39,50,51]. Globally, the $\mathrm{M}$ molecular form was widespread in the highly urbanized coastal area and in around major urban centres in the forest area. Its distribution was restricted to the southernmost localities, and it was not found above latitude $5^{\circ} \mathrm{N}$. The $\mathrm{S}$ form was more widespread and was found in all geographical areas sampled, albeit at a lower frequency than the $\mathrm{M}$ form in urbanized areas in the South. It was highly predominant in the central part of the country including western highlands and occurred together with An. arabiensis in northern savannas. This distribution pattern is consistent with previous reports $[22,38,39,52]$. Physical environmental factors such as temperature, water vapour pressure, evapotranspiration, sunlight exposure, annual rainfall and 


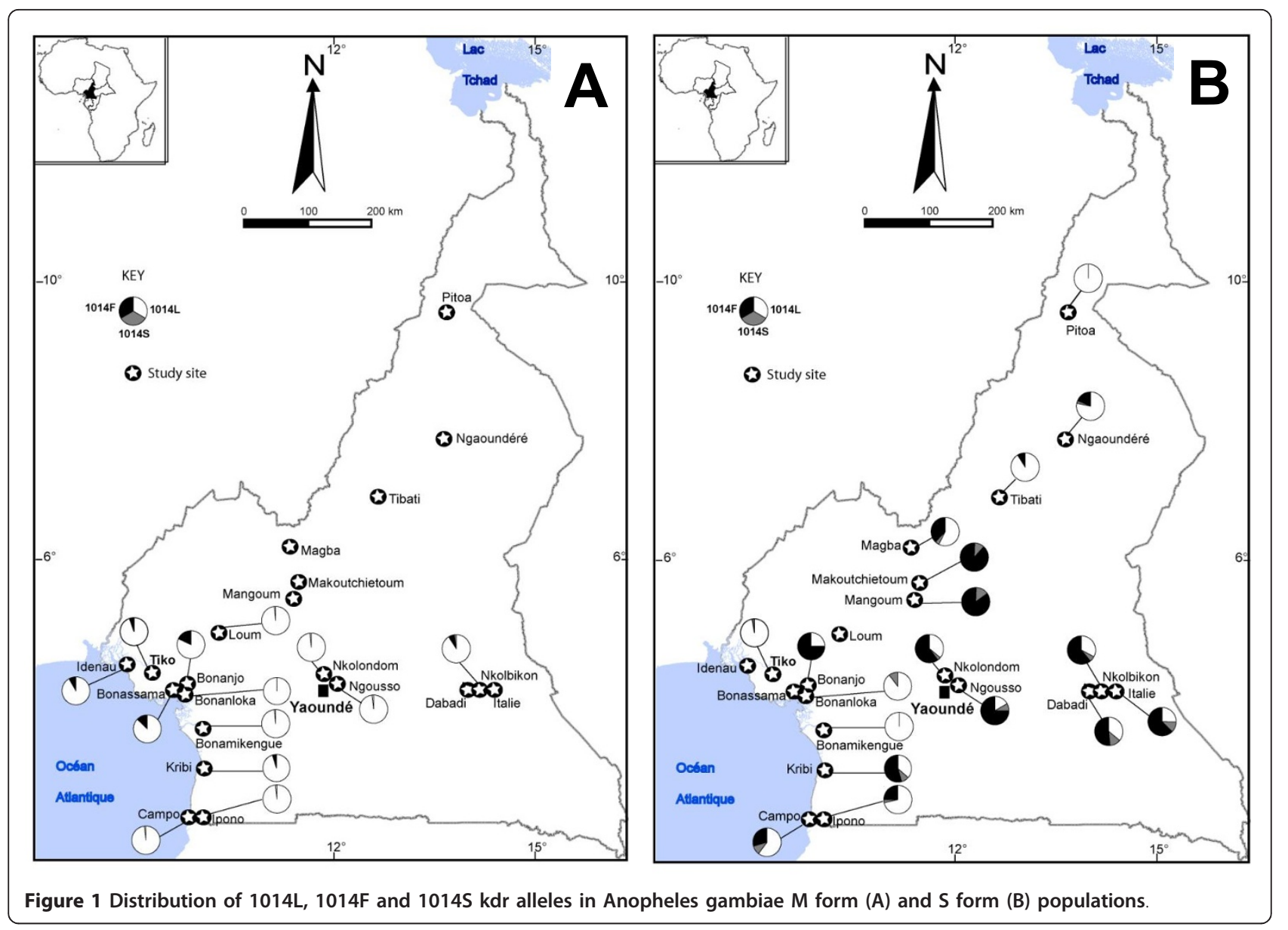

land cover have been shown to influence the distribution of the $\mathrm{M}$ and $\mathrm{S}$ forms of An. gambiae at the geographical scale of the country in Cameroon [39]. Other biotic and abiotic factors need to be involved to explain the heterogeneous distribution observed at a more local geographical scale. In this regard, it is important to stress that these vector populations typically show temporal variations in their relative abundance [23]. This might lead to mosaic patterns of species occurrences along a geographical transect, such as observed in the present study in areas where the habitat is globally equally favourable to both species/molecular forms. Moreover, biotic interactions occurring at the larval and/or adult stages such as competition, predation and parasitism might further determine the population's structure and impact on species balance locally, as recently evidenced from studies conducted on An. gambiae populations of the $\mathrm{M}$ and $\mathrm{S}$ form in Burkina Faso $[53,54]$. Finally, anthropogenic factors, such as chemical insecticide usage in public health and agriculture may be a key factor in selecting one or the other of the molecular form, according to the resistance mechanism (s) it is armed with.
The coexistence of both 1014F and 1014S $k d r$ alleles was evidenced in the $\mathrm{M}$ molecular form as well as in the $\mathrm{S}$ form in this study, although both alleles occurred at a much higher frequency in S-form than in $\mathrm{M}$-form populations. Some authors have suggested that there is a link between the $1014 \mathrm{~F}$ and $1014 \mathrm{~S} k d r$ alleles and resistance phenotypes to DDT and pyrethroid insecticides in field populations of Anopheles gambiae s.s $[5,55,56]$. However, questions over the reliability of inferring resistance phenotype based solely on the diagnosis of $k d r$ genotype have been raised, because correlations between phenotype and $k d r$ genotype are obscure in some instances [57]. Other authors argue that the $k d r$ alleles cannot alone confer resistance to DDT and pyrethroid insecticides in the absence of hypothetical, thus far unidentified co-factors $[57,58]$. Alone or in combination with the high activity level of detoxification enzyme systems (monooxygenases, glutathione-S-transferases and non-specific esterases) reported in some mosquito populations of our study area [24-26], the 1014F and $1014 \mathrm{~S} k d r$ alleles identified in most of our collection sites could have an impact on the high levels of $A n$. gambiae s.l resistance to these insecticides reported 
throughout Cameroon [59]. On the whole results presented in this study shows a rise in frequency of resistant $k d r$ alleles (e.g., 1014F and 1014S) in both molecular forms compared to previous studies related to the frequency of these alleles in the country [22,23,27]. However, these frequencies, particularly that of the 1014F recorded in the $\mathrm{M}$ molecular form are lower compared to that obtained in a recent survey carried out in Cameroon where the frequency of this allele was 68\% in Douala and 44\% in Yaounde [60]. These alleles were not detected in An. arabiensis nor An. melas specimens. None of them has not yet been identified in $A n$. melas whereas several studies reported their presence in An. arabiensis in Kenya [61], Sudan [62,63] and Cameroon [22]. The absence of these alleles in the present samples suggests their recent introduction in An. arabiensis in Cameroon where they seem to occur at a very low frequency. Within An. gambiae s.s, both 1014F and $1014 \mathrm{~S}$ alleles were previously reported in Cameroon $[27,64]$. In neighbouring countries, at least one of these alleles has been found, e.g. in Equatorial Guinea [65], Gabon [66], Central Africa Republic [67], Chad [68] and Nigeria [69] emphasizing the spread of the $k d r$ mutations in Central Africa [10]. However, again, referring to results based on cross sectional studies calls for caution and care must be taken in predicting absence of these alleles in a given zone/area of the country.

The uneven distribution of $k d r$ alleles between molecular forms and species of the An. gambiae complex probably reflects different molecular evolution dynamics within species and forms and different levels of exposure to insecticide-driven selection pressure [10,70-72]. A significant heterozygote deficit was noted in some $\mathrm{M}$ and $\mathrm{S}$ form populations when $k d r$ genotypic frequencies were compared to Hardy-Weinberg proportions. This heterozygote deficit was observed in sites where chemical insecticides particularly pyrethroids have been reported to be commonly used for agriculture, wood/forest exploitation and public health purposes $[23,72]$. Although the resistance genotype was not determined in this study, we think the selection pressure from agricultural use of both DDT and pyrethroids, as well as to DDT-based vector control campaigns undertaken in the 1950s may confer a selective advantage to resistant homozygote individuals because $k d r$ is a recessive trait [5].

The selection of the $k d r$ alleles has been evidenced with the use of ITNs [73,74]. ITNs or LLINs are distributed on a large scale in Cameroon since $\approx 10$ years by the National Program of Malaria Control. This may constitute an additional source for the selection pressure of $k d r$ alleles in several Anopheles gambiae mosquito vector populations in Cameroon. Here, the highest frequencies of $k d r$ alleles were recorded in urban areas (e.g., Ngousso, Dabadi, Nkolbikon and
Italie) and agricultural settings (e.g., Nkolondom, Campo and Makoutchietoum) where large amounts of chemical insecticides are commonly used for diseases vector control, personal protection against nuisances and crop/wood protection [23]. The 1014F and 1014S $k d r$ alleles were initially identified in Anopheles gambiae mosquitoes from West [5] and East [6]. Africa respectively. Their co-occurrence and rise in frequency in mosquito vector populations in Cameroon testifies of the ongoing geographical spread of both alleles invading wild Anopheles gambiae populations throughout Africa.

\section{Conclusions}

In West Africa, ITNs were reported to provide personal protection even against $k d r$-based resistant An. gambiae populations [75-77], but recent studies suggested reduced efficacy of ITNs and IRS in areas with high frequencies of 1014F $k d r$ allele [78]. High frequencies of $k d r$ alleles in malaria mosquito populations in Cameroon prompts the need for close monitoring of vector susceptibility levels to insecticides and tracing of resistance mechanisms in order to devise adapted vector control measures and prevent failure in areas where these methods are implemented.

\section{Acknowledgements}

We wish to thank Roger Beyené for his help in mosquito sampling, Soulemanou and the local communities for their kind collaboration in the fields. Financial support was provided by UNICEF/UNDP/World Bank/WHO/ Special Programme for Research and Training in Tropical Diseases (TDR): Multilateral Initiative on Malaria Re-entry Grant number A41481 to J.E.

\section{Author details}

'Organisation de Coordination pour la lutte contre les Endémies en Afrique Centrale, Yaoundé, Cameroun. 'Université de Yaoundé I, Yaoundé, Cameroun. ${ }^{3}$ Faculty of Medicine and Pharmaceutical Sciences, University of Douala, Cameroun. ${ }^{4}$ Institut de Recherche pour le Développement (IRD), UR016, Bobo-Dioulasso, Burkina Faso.

\section{Authors' contributions}

JE and FS conceived the study. JE, FS, RM, and PN designed the study protocol; JE, PN, MC and JCT performed field work and bioassays; PN performed molecular analyses, interpreted the data and drafted the manuscript which was critically revised by JE, RM, MC and FS. All the authors read and approved the final manuscript.

\section{Competing interests}

The authors declare that they have no competing interests.

Received: 12 July 2011 Accepted: 28 October 2011

Published: 28 October 2011

\section{References}

1. Hemingway J, Ranson $\mathrm{H}$ : Insecticide resistance in insect vectors of human disease. Annual Review of Entomology 2000, 45:371.

2. Coleman $M$, Hemingway J: Insecticide resistance monitoring and evaluation in disease transmitting mosquitoes. Journal of Pest Science 2007, 32(2):69-76.

3. Hemingway J, Hawkes NJ, Mc Carroll L, Ranson H: The molecular basis of insecticide resistance in mosquitoes. Insect Biochemistry and Molecular Biology 2004, 34:653-65. 
4. Williamson MS, Martinez-Torrez D, Hick CK, Devonshire AL: Identification of mutations in the housefly para-type sodium channel gene associated with knockdown resistance $(k d r)$ to pyrethroid insecticides. Molecular and General Genetics 252:51-60.

5. Martinez-Torres D, Chandre F, Williamson MS, Darriet F, Bergé JB, Devonshire AL, Guillet P, Pasteur N, Pauron D: Molecular characterization of pyrethroid knockdown resistance $(k d r)$ in the major malaria vector Anopheles gambiae s.s. Insect Molecular Biology 1998, 7:179-184.

6. Ranson $\mathrm{H}$, Jensen $\mathrm{B}$, Vulvule JM, Wang $\mathrm{X}$, Hemingway J, Collins FH: Identification of a point mutation in the voltage-gated sodium channel gene of Kenyan Anopheles gambiae associated with resistance to DDT and pyrethroids. Insect Molecular Biology 2000, 9:491-497.

7. Williamson MS, Denholm I, Bell CA, Devonshire AL: Knockdown resistance $(k d r)$ to DDT and pyrethroid insecticides maps to a sodium channel gene locus in the housefly (Musca domestica). Molecular and General Genetics 1993, 240:17-22

8. Martinez-Torrez D, Foster SP, Field LM, Devonshire AL, Williamson MS: A sodium channel point mutation is associated resistance to DDT and pyrethroid insecticide in the peach-potato aphid, Myzus persicae (Sulzer) (Hemiptera Aphididae). Insect Molecular Biology 1999, 8:339-346.

9. Schuler TH, Martinez-Torres D, Thompson AJ, Denholm I, Devonshire AL, Duce IR, Williamson MS: Toxicological, electrophysiological and molecular characterization of knockdown resistance to pyrethroid insecticides in the diamondback moth, Plutella xylostella (L). Pesticide Biochemistry and Physiology 1998, 59:169-182.

10. Santolamazza F, Calzetta M, Etang J, Barrese E, Dia I, Caccone A, Donnelly MJ, Petrarca V, Simard F, Pinto J, Della Torre A: Distribution of knockdown resistance mutations in Anopheles gambiae molecular forms in West and West-Central Africa. Malaria Journal 2008, 7:74.

11. Kelly-Hope L, Ranson H, Hemingway J: Lessons from the past: managing insecticide resistance in malaria control and eradication programmes. Lancet Infectious Diseases 2008, 8:387-389.

12. Mittal PK, Adak T, Sharma VP: Acute toxicity of certain organochlorine, organophosphorus, synthetic pyrethroid and microbial insecticides to the mosquito fish Gambusia affinis (Baird and Girard). Indian Journal of Malariology 1991, 28:167-70.

13. Zaim M, Aitio A, Nakashima N: Safety of pyrethroid-treated nets. Medical and Veterinary Entomology 2000, 14:1-5.

14. Zaim M, Jambulingam P: Global insecticide use for vector-borne disease control. 3 edition. World Health Organization; 2007.

15. WHO: Malaria vector control and personal protection. WHO Technical Report Series 2006, № 936.

16. Bronzan RN, McMorrow ML, Kachur SP: Diagnosis of malaria: challenges for clinicians in endemic and non endemic regions. Molecular Diagnosis Therapy of Infectious Diseases 2008, 12(5):299-306.

17. Kouznetsov RI: Malaria control by application of indoor spraying of residual insecticides in tropical Africa and its impact in population health. Tropical Doctor 1977, 7:81-91.

18. Mabaso MLH, Sharp B, Lengeler : Historitical review of malaria control in southern Africa with emphasis on the use of indoor residual housespraying. Tropical Medecine and International Health 2004, 9:846-856.

19. Breman JG, Alilio MS, Mills A: Conquering the intolerable burden of malaria: what's new, what's needed: a summary. American Journal of Tropical Medicine and Hygiene 2004, 71:1-15.

20. PNLP, 2002: Plan stratégique national de lutte contre le paludisme au Cameroun.125.

21. Etang J, Manga L, Chandre F, Guillet P, Fondjo E, Mimpfoundi R, Toto JC, Fontenille D: Insecticide susceptibility status of Anopheles gambiae s.l. (Diptera: Culicidae) in the Republic of Cameroon. Journal of Medical Entomology 2003, 40:491-497.

22. Ndjemaï HNM, Patchoké S, Atangana J, Etang J, Simard F, Bilong Bilong CF, Reimer L, Cornel A, Lanzaro CG, Fondjo E: The distribution of insecticide resistance in Anopheles gambiae s.l populations from Cameroon: an update. Transactions of the Royal Society of Tropical Medicine and Hygiene 2008, 103(11):1127-38.

23. Nwane P, Etang J, Chouaibou M, Toto JC, Kerah-Hinzoumbé C, Mimpfoundi R, Awono-Ambene HP, Simard F: Trends in DDT and pyrethroid resistance in Anopheles gambiae s.s. populations from urban and agro-industrial settings in southern Cameroon. BMC Infectious Diseases 2009, 9:163.
24. Etang J, Manga L, Toto JC, Guillet P, Fondjo E, Chandre F: Spectrum of metabolic-based resistance to DDT and pyrethroids in Anopheles gambiae s.l populations from Cameroon. Journal of Vector Ecology 2007, 32(1):123-133.

25. Chouaiibou M, Etang J, Brevault T, Nwane P, Hinzoumbé CK, Mimpfoundi R, Simard F: Dynamics of insecticide resistance in the malaria vector Anopheles gambiae s.l from an area of extensive cotton cultivation in Northern Cameroon. Tropical Medicine and International Health 2008, 13(4):1-11.

26. Müller P, Chouaibou M, Pignatelli P, Etang J, Walker ED, Donnelly MJ, Simard F, Ranson H: Pyrethroid tolerance associated with elevated expression of antioxidants and agricultural practice in Anopheles arabiensis sampled from an area of cotton fields in Northern Cameroon. Molecular Ecology 2008, 17(4):1145-1155.

27. Etang J, Fondjo E, Chandre F, Brengues C, Nwane P, Chouaïbou M, Ndjemai $\mathrm{H}$, Simard F: First report of knockdown mutations in the malaria vector Anopheles gambiae from Cameroon. American Journal of Tropical Medicine and Hygiene 2006, 74:795-797.

28. Suchel JB: Les climats du Cameroun. Thèse de Doctorat d'Etat. Université de Bordeau III; 1987, 1186.

29. Tsalefack M: In Climates of Cameroon. Atlas of Cameroon. Edited by: Ben Yahmed D, Houstin N, Seignobos C. Les Editions JA-Edition du Jaguar, Paris; 105-119.

30. Silver JB: Mosquito ecology: field sampling methods, Third edition 2008, 1494.

31. Gillies MT, De Meillon B: The anophelinae of Africa south of the sahara. Publication of the South African Institute for Medical Research;54:343.

32. Gillies MT, Coetzee M: Supplement. to the Anophelinae of Africa south of the Sahara. (Afrotropical region). South African Institute for Medical Research 1987, 55:143.

33. Collins FH, Mendez MA, Razmussen MO, Mehaffey PC, Besansky NJ, Finnerty V: A ribosomal RNA gene probe differentiates member species of Anopheles gambiae complex. American Journal of Tropical Medicine and Hygene 1987, 37:37-41.

34. Fanello C, Santolamazza F, della Torré A: Simultaneous identification of species and molecular forms of the Anopheles gambiae complex by PCRRFLP. Medical and Veterinary Entomology 2002, 16:461-464.

35. Lynd A, Ranson H, McCall PJ, Randle NP, Black WC IV, Walker ED, Donnelly MJ: A simplified high-throughput method for pyrethroid knockdown resistance $(k d r)$ detection in Anopheles gambiae. Malaria Journal 2005, 4:16

36. Raymond M, Rousset F: An exact test of population differentiation. Evolution 1995, 49:1280-1283.

37. Coetzee M, Craig M, Le Sueur D: Distribution of african malaria mosquitoes belonging to Anopheles gambiae complex. Parasitology Today 2000, 16(2):74-77.

38. Wondji C, Simard F, Petrarca V, Etang J, Santolamazza F, Della Torré A, Fontenille D: Species and populations of the Anopheles gambiae complex in Cameroon with special emphasis on chromosomal and molecular forms of Anopheles gambiae s.s. Journal of Medical Entomology 2005, 42(6):998-1005.

39. Simard F, Ayala D, Kamdem GC, Pombi M, Etouna J, Ose K, Fotsing JM, Fontenille D, Besansky NJ, Costantini C: Ecological niche partitioning between Anopheles gambiae molecular forms in Cameroon: the ecological side of speciation. BMC Ecology 2009, 9:17.

40. Ayala D, Costantini C, Ose K, Kamdem GC, Antonio-Nkondjio C, Agbor JP, Awono-Ambene P, Fontenille D, Simard F: Habitat suitability and ecological niche profile of major malaria vectors in Cameroon. Malaria Journal 2009, 8:307.

41. Bryan JH, Petrarca V, Di Deco MA, Coluzzi M: Adult behaviour of members of the Anopheles gambiae complex in the Gambia with special reference to An. melas and its chromosomal variants. Parassitologia 1987, 29:221-249.

42. Diop A, Molez JF, Konate L, Fontenille D, Gaye O, Diouf M, Diagne M, Faye O: Role of Anopheles melas Theobald (1903) on malaria transmission in the a mangrove swamp in Saloum (Senegal). Parasite 2002, 9:239-246.

43. dellaTorre A, Fanello C, Akogbeto M, Dossou-yovo J, Favia G, Petrarca V, Coluzzi M: Molecular evidence of incipient peciation within Anopheles gambiae s.s. in West Africa. Insect Molecular Biology 2001, 10:9-18. 
44. Favia G, Lanfrancotti A, Spanos L, Sidén-Kiamos I, Louis C: Molecular characterization of ribosomal DNA polymorphisms discriminating among chromosomal forms of Anopheles gambiae s.s. Insect Molecular Biology 2001, 10:19-23.

45. Gentile G, Slotman M, Ketmaier V, Powell JR, Caccone A: Attempts to molecularly distinguish cryptic taxa in Anopheles gambiae s.s. Insect Molecular Biology 2001, 10:25-32.

46. Stump AD, Fitzpatrick MC, Lobo NF, Traore S, Sagnon N, Costantini C, Collins FH, Besansky NJ: Centromere-proximal differentiation and speciation in Anopheles gambiae. Procedure of the National Academy of Science USA 2005, 102:15930-15935.

47. Turner TL, Hahn MW: Locus and population specific selection and differentiation between incipient species of Anopheles gambiae. Molecular Biology Evolution 2007, 24:2132-2138.

48. dellaTorre A, Costantini C, Besansky NJ, Caccone A, Petrarca V, Powell JR, Coluzzi M: Speciation within Anopheles gambiae - the glass is half full. Science 2002, 298:115-117.

49. Lehmann T, Diabate A: The molecular forms of Anopheles gambiae: A phenotypic perspective. Infection, Genetics and Evolution 2008, 8:737-746.

50. Wondji C, Simard F, Fontenille D: Evidence for genetic differentiation between the molecular form $\mathrm{M}$ and $\mathrm{S}$ within the forest chromosomal form of Anopheles gambiae in an area of sympatry. Insect Molecular Biology 2002, 11(1):11-19.

51. Esnault C, Boulesteix M, Duchemin JB, Koffi AA, Chandre F, Dabiré R, Robert V, Simard F, Tripet F, Donnelly MJ, Fontenille D, Biémont C: High genetic differentiation between the $\mathrm{M}$ and $\mathrm{S}$ molecular forms of Anopheles gambiae in Africa. PLOS ONE 3(4):e1968.

52. Bigoga JD, Manga L, Titanji VPK, Etang J, Coetzee M, Leke RGF: Susceptibility of Anopheles gambiae Giles (Diptera: Culicidae) to pyrethroids, DDT and carbosulfan in coastal Cameroon. African Entomology 2007, 15(1):133-139.

53. Diabate A, Dabire RK, Millogo N, Lehmann T: Evaluating the effect of postmating isolation between molecular forms of Anopheles gambiae (Diptera: Culicidae). Journal of Medical Entomology 2007, 44:60-64.

54. Gimonneau G, Bouyer J, Morand S, Besansky NJ, Diabate A, Simard F: A behavioral mechanism underlying ecological divergence in the malaria mosquito Anopheles gambiae. Behavioral Ecology 2010, 21(5):1087-1092.

55. Chandre F, Darriet F, Manga L, Akogbéto M, Faye O, Mouchet J, Guillet Pierre: Pyrethroid cross resistance spectrum among populations of Anopheles gambiae s.s from Côte d'Ivoire. Journal of the American Mosquito Control Association 1999, 15:53-59.

56. Donnelly MJ, Corbel V, Weetman D, Wilding CS, Williamson MS, Black WCt: Does $k d r$ genotype predict insecticide resistance phenotype in mosquitoes? Trends in Parasitology 2009, 25:213-9.

57. Brooke DB, Koekemoer LL: Major effect genes or loose confederations? The development of insecticide resistance in the malaria vector Anopheles gambiae. Parasites \& Vectors 2010, 3:74.

58. Brooke DB: Kdr: can a single mutation produce an entire insecticide resistance phenotype? Transactions of the Royal Society of Tropical Medicine and Hygiene 2008, 102:524-525.

59. Etang J, Manga L, Chandre F, Guillet P, Fondjo E, Mimpfoundi R, Toto JC, Fontenille D: Insecticide susceptibility status of Anopheles gambiae s.l. (Diptera: Culicidae) in the Republic of Cameroon. Journal of Medical Entomology 2003, 40:491-497.

60. Antonio-Nkondjio C, Tene Fossog B, Ndo C, Menze Djantio B, Zebaze Togouet S, Awono-Ambene P, Costantini C, Wondji C, Ranson H: Anopheles gambiae distribution and insecticide resistance in the cities of Douala and Yaoundé (Cameroon): influence of urban agriculture and pollution. Malaria Journal 2011, 10:154

61. Verhaeghen K, Van Bortel W, Roelants P, Backeljau T, Coosemans M: Detection of the East and West African kdr mutations in Anopheles gambiae and Anopheles arabiensis using a new assay based on FRET/ Melt Curve analysis. Malaria Journal 2006, 5:16.

62. Abdalla H, Matambo TS, Koekemoer LL, Mnzava AP, Hunt RH, Coetzee M: Insecticide susceptibility and vector status of natural populations of Anopheles arabiensis from Sudan. Transactions of the Royal Society of Tropical. Medicine and Hygiene 2008, 102:263-271.

63. Himeidan YE, Chen H, Chandre F, Donnelly MJ, Yan G: Permethrin and DDT resistance in the malaria vector Anopheles arabiensis from Eastern Sudan. American Journal of Tropical Medicine and Hygiene 2007, 77:1066-1068.
64. Reimer L, Fondjo E, Patchoké S, Diallo B, Lee Y, Arash NG, Ndjemai HM, Atangana J, Traoré SF, Lanzaro G, Cornel JA: Relationship between $k d r$ mutation and resistance to pyrethroid and DDT insecticides in natural populations of Anopheles gambiae. Journal of Medical Entomology 2008, 45(2):260-266.

65. Reimer $\sqcup$, Tripet F, Slotman M, Spielman A, Fondjo, Lanzaro GC: An unusual distribution of the $k d r$ gene among populations of Anopheles gambiae on the island of Bioko, Equatorial Guinea. Insect Molecular Biology 2005, 14:683-688.

66. Pinto J, Lynd A, Elissa N, Donnelly MJ, Costa C, Gentile G, Caccone A, Do Rosário VE: Co-occurrence of East and West African kdr mutations suggests high levels of resistance to pyrethroid insecticides in Anopheles gambiae from Libreville, Gabon. Medical and Veterinary Entomology 2006, 20:27-32.

67. Weill M, Chandre F, Brengues C, Manguin S, Akogbéto M, Pasteur N, Guillet P, Raymond M: The kdr mutation occurs in the Mopti form of Anopheles gambiae s.s. through introgression. Insect Molecular Biology 2000, 9:451-455.

68. Kerah-Hinzoumbé C, Péka M, Nwane P, Donan-Gouni I, Etang J, SamèEkobo A, Frédéric Simard: Insecticide resistance in Anopheles gambiae from southwestern Chad, Central Africa. Malaria Journal 2008, 7:192.

69. Awolola TS, Oduola AO, Oyewole IO, Obansa JB, Amajoh CN, Koekemoer LL, Coetzee M: Dynamics of knockdown pyrethroid insecticide resistance alleles in a field population of Anopheles gambiae s.s in southwestern Nigeria. Journal Vector Borne Diseases 2007, 44:181-188.

70. Pinto J, Lynd A, Vicente JL, Santolamazza F, Randle NP, Gentile G, Moreno M, Simard F, Charlwood JD, do Rosa'rio VE, Caccone A, della Torre A, Donnelly MJ: Multiple origins of knockdown resistance mutations in the afrotropical mosquito vector Anopheles gambiae. PLOS ONE 2(11):e1243.

71. Etang J, Vicente JL, Nwane P, Chouaibou M, Morlais I, Do Rosario VE, Simard F, Awono-Ambene HP, Toto JC, Pinto J: Polymorphism of intron-1 in the voltage-gated sodium channel of Anopheles gambiae s.s. populations from Cameroon with emphasis on insecticide knockdown resistance mutations. Molecular Ecology 2009, 18:3076-3086.

72. Dabiré KR, Diabaté A, Namountougou M, Toé KH, Ouari A, Kengne $P$, Bass C, Baldet T: Distribution of pyrethroid and DDT resistance and the L1014F kdr mutation in Anopheles gambiae s.l. from Burkina Faso (West Africa). Transactions of the Royal Society of Tropical Medicine and Hygiene 2009.

73. Kolaczinski JH, Fanello C, Hervé JP, Conway DJ, Carnevale P, Curtis CF: Experimental and molecular genetic analysis of the impact of pyrethroid and non-pyrethroid insecticide impregnated bednets for mosquito control in an area of pyrethroid resistance. Bulletin of Entomology Research 2000, 90:125-132.

74. Stump AD, Atieli FK, Vulvule JM, Besanky NJ: Dynamics of the pyrethroid knockdown resistance allele in the western Kenyan populations of Anopheles gambiae in response to insecticide treated bed net trials. American Journal of Tropical Medicine and Hygiene 2004, 70:591-596.

75. Darriet F, N'Guessan R, Koffi A, Konan L, Doannio JMC, Chandre F, Carnevale $P$ : Impact de la résistance aux pyréthrinoïdes sur l'efficacité des moustiquaires imprégnées dans la prévention du paludisme: résultats des essais en cases expérimentales avec la deltaméthrine SC. Bulletin de la Société de Pathologie Exotique 2000, 93:131-134.

76. Henry MC, Assi SB, Rogier C, Dossou-Yovo J, Chandre F, Guillet P, Carnevale P: Protective efficacy of lambda-cyhalothrin treated nets in Anopheles gambiae pyrethroid resistance areas of Côte d'ivoire. American Journal of Tropical Medicine and Hygiene 2005, 73:859-864.

77. Dabiré RK, Diabaté A, Baldet T, Paré-Toé L, Guiguemdé RT, Ouedraogo JB, Skovmand $\mathrm{O}$ : Personal protection of long lasting insecticide treated nets in areas of Anopheles gambiae s.s. resistance to pyrethroids. Malaria Journal 2006, 5:12.

78. N'Guessan R, Corbel V, Akogbéto M, Rowland M: Reduced efficacy of insecticide-treated nets and indoor residual spraying for malaria control in pyrethroid resistance area, Benin. Emerging Infectious Diseases 2007, 13:199-206.

doi:10.1186/1756-0500-4-463

Cite this article as: Nwane et al:: Kdr-based insecticide resistance in Anopheles gambiae S.s populations in Cameroon: spread of the L1014F and L1014S mutations. BMC Research Notes 2011 4:463. 